\title{
Removal of textile dye by mixed oxide-LDH: kinetics, isotherms of the adsorption and retention mechanisms studies
}

\author{
R. Sadik, R. Lahkale, N.Hssaine, M. Diouri, E.M. Sabbar* \\ Laboratory of Physic and Chemistry of Materials (LPCM).Department of Chemistry, University \\ ChouaîbDoukkali, El Jadida, MOROCCO.
}

\begin{abstract}
The removal of theorangeaciddye7was carried out byadsorptionusing a mixedoxide obtainedaftercalcinationof alayered double hydroxide $(L D H)$ also calledanionicclay.

This work requires the control and optimization of variousparameters such as the contact time, thepH, the mass of adsorbentandthe initial concentrationofdye.

The removal of the orange acid dye 7 is arapidadsorptionprocess, theequilibriumtemperature isreached after34min. the kinetic data were analyzed using the pseudo first-order and pseudo second-order models and they were found to fit very well the pseudo second order. Thisis confirmedwithfast kineticsmodeling ofexperimental dataaccording to thepseudosecond-order.Furthermore, the adsorption ofthedye follows theLangmuir isotherm, withan adsorptionof about $328.94 \mathrm{mg} / \mathrm{gcapacity}$. This retentionfar exceedsthat obtainedby unburned HDL. In order to clarifythe adsorptionmechanism, we havealso studiedtheintraparticlediffusion. The useof a mixed oxideasadsorbent hasallowed us toregeneratea newdye-precursor HDL.
\end{abstract}

Keywords: Layered Double Hydroxides, Mixed Oxide,OrangeAciddye7, Adsorption, Kinetic.

\section{Introduction}

Annually, approximately $710^{5}$ tons of dyes are produced, and approximately $710^{4}$ tons/year are discarded by industries, including the textile, rubber, food, paper and plastic industries [1-3]

Because of their high organic matter concentrations and their intense colors, the effluents discarded by the food industry are an important source of pollution for water bodies. When discharged into streams, these effluents reduce the transmission ofsunlight into the depleted dissolved oxygen zone [4-6] and may cause changes in aquatic biota (particularly near the release point).Thus, it becomes necessary to remove these materials before they are mixed with natural and unpolluted water bodies [2].

The removal of color from wastewater is a major environmental problem because it is difficult to treat colored wastewaters with conventional methods [3].

Among the various types of processes for dye removal (physical, chemical, biological methods, electrochemical oxidation and adsorption methods), the adsorption process is one of the most efficient [7-10]. Activated carbon is the most popular adsorbent due to its high adsorption capacity for organic and inorganic pollutants [4].Moreover, the use of low costmaterials for adsorption has attracted attention as a color removal technique. For example, natural clays, bagasse fly ash, chitosan and other adsorbents have been used [10-14].

Layered double hydroxides (LDHs), also known as hydrotalcitelike compounds, have attracted considerable attention in recent years because of their potential industrial uses, which include their use as adsorbents, ion exchangers, catalysts and drug carriers [15-17].

It is from this perspective that our research is interested in the removal by adsorption of a class of textile dye that is common and widespread worldwide. Indeed bleaching is carried out using a mixed oxide of the LDH as adsorbent, given its high adsorption properties in comparison to its uncalcined precursor.

These compounds which are a class of layered compounds that are derived from the structure of mineral brucite, $\mathrm{Mg}(\mathrm{OH})_{2}$, can be represented with the general formula $\left[\mathrm{M}^{\mathrm{II}}{ }_{(1-\mathrm{x})} \mathrm{M}^{\mathrm{III}}{ }_{\mathrm{x}}(\mathrm{OH})_{2}\right]^{\mathrm{x}+}\left[\mathrm{A}^{\mathrm{n}-}{ }_{\mathrm{x} / \mathrm{n}}, \mathrm{zH}_{2} \mathrm{O}\right]^{\mathrm{x}}$ where $\mathrm{M}^{\mathrm{II}}$ and $\mathrm{M}^{\mathrm{III}}$ are any divalent and trivalent metal cations, $\mathrm{A}^{\mathrm{n}}$ - is the interlayer anions, and $\mathrm{x}$ is $\mathrm{M}^{\mathrm{II}} / \mathrm{M}^{\mathrm{II}}$ $+\mathrm{M}^{\mathrm{III}}$ molar ration, determiningthecharge density of thesheet, andtherefore, the amount ofinterlayersites that can beoccupiedby anions.

\subsection{Material}

\section{Materials And Method}

\subsubsection{Synthesis of the adsorbent}

The preparation of the precursor was carried out by the method of cooprecipitation described by Reichle[18]. $\left(\mathrm{MgCl}_{2}, 6 \mathrm{H}_{2} \mathrm{O}\right)$ and $\left(\mathrm{AlCl}_{3}, 6 \mathrm{H}_{2} \mathrm{O}\right)$ are dissolved in distilled water with a molar ratio $(\mathrm{Mg} / \mathrm{Al}=3)$. The $\mathrm{pH}$ ofthe reaction mixture was maintained constant at 10.0 by addition of a mixture of $\mathrm{NaOH}$ and $\mathrm{Na}_{2} \mathrm{CO}_{3}$ $\left([\mathrm{NaOH}] /\left[\mathrm{Na}_{2} \mathrm{CO}_{3}\right]=4\right)$. The gel was stirred at room temperature for $48 \mathrm{~h}$. The clay obtained was washed by centrifugation with distilled water and dried at $60^{\circ} \mathrm{C}$ for $48 \mathrm{~h}$. The chemical formula of the clay prepared is 
$\mathrm{Mg}_{3} \mathrm{Al}(\mathrm{OH})_{8}\left(\mathrm{CO}_{3}\right)_{0.5}, 3.1 \mathrm{H}_{2} \mathrm{O}$ (noted HT). The adsorbent used in this study is obtained by calcination of HT at $500^{\circ} \mathrm{C}$ during $5 \mathrm{~h}$. The formula of this mixed oxide is $\mathrm{Mg}_{2.95} \mathrm{AlO}_{4.45}$ (noted HT500)

\subsubsection{Adsorbate}

Theadsorbateisatextile dye calledorange7acid (denotedAO7), thestructural formulaisschematizedin Fig 1:<smiles>[NH3+]OS(=O)(=O)c1ccc(/N=N/c2c(O)ccc3ccccc23)cc1</smiles>

Figure.1.Chemical structure of orange 7 dye acid (AO7)

\subsection{Analysis and characterization}

Chemical compositions of metals were determined by ICP (Induced coupled plasma (ICP) measurements)Emission Spectrophotometer. IR spectra were recorded in the range of $4000-400 \mathrm{~cm}^{-1}$ byFT-IR8400S SHIMADZU spectrometer using KBr pellets (2\%).

The anionic clay was characterized by X-ray diffraction using 2 -D-diffractometer of Bruker-AXS PHASER using copper $\mathrm{K}_{\alpha 1}$ radiation $(1.54056 \AA)$ and $\mathrm{K}_{\alpha 2}(1.54439 \AA)$ and Scanning Electron Microscopy (SEM) (type FEI Quanta 200). The dosage was carried $(\lambda=483 \mathrm{~nm})$ out by spectrophotometry using a spectrophotometer type RAYLEIGH-Vis Spectrophotometer 7220G.

\subsection{Batch Adsorption Studies}

These experiments were performed by contacting $20 \mathrm{mg}$ of HT500 with $50 \mathrm{ml}$ of AO7 effluent at desired contact time, $\mathrm{pH}$, adsorbent mass and initial $\mathrm{AO} 7$ concentration.

Once the equilibrium time was reached, the adsorbent was recovered by centrifugation. The amount of $\mathrm{AO} 7$ retained per unit mass of solid at equilibrium is calculated by:

$$
\mathrm{q}_{\mathrm{e}}=\left(\mathrm{C}_{0}-\mathrm{C}_{\mathrm{e}}\right) \mathrm{V} / \mathrm{m} \quad \text { i.e., (1) }
$$

Where $\mathrm{q}_{\mathrm{e}}(\mathrm{mg} / \mathrm{g})$ is the amount of $\mathrm{AO} 7$ adsorbed per gramof adsorbent; $\mathrm{m}(\mathrm{g})$ is the mass of the adsorbent, $\mathrm{C}_{0}$ and $\mathrm{C}_{\mathrm{e}}(\mathrm{mg} / \mathrm{L})$ are the $\mathrm{AO} 7$ concentrations respectively at $\mathrm{t}=0$ and at equilibrium.

The AO7 removal efficiency or AO7 uptake (\%) is calculated by:

$$
(\% \text { AO7 })=100\left(\mathrm{C}_{0}-\mathrm{C}_{\mathrm{e}}\right) / \mathrm{C}_{0} \text { i.e., }(2)
$$

\section{Results And Discussion}

\subsection{Characterizationof LDH precursor}

\subsubsection{X-ray diffraction}

The typical XRD pattern (Fig. 1) shows a lamellar structure of LDH material. The XRD patterns were indexed in theR-3m space group, $\mathrm{c}$ the lattice parameter corresponding to three times theinterlayer distances $\left(\mathrm{c}=3 \mathrm{~d}_{003}\right)$. The peak (110) indicates the intermetallic distance used to calculate a lattice parameter $\left(\mathrm{a}=2 \mathrm{~d}_{110}\right)$.

The values of the parameters $\mathrm{c}$ and a are respectively 23.13 and 3.02 $\mathrm{A}$. These values are similar to those reported in literature [19-20]. 


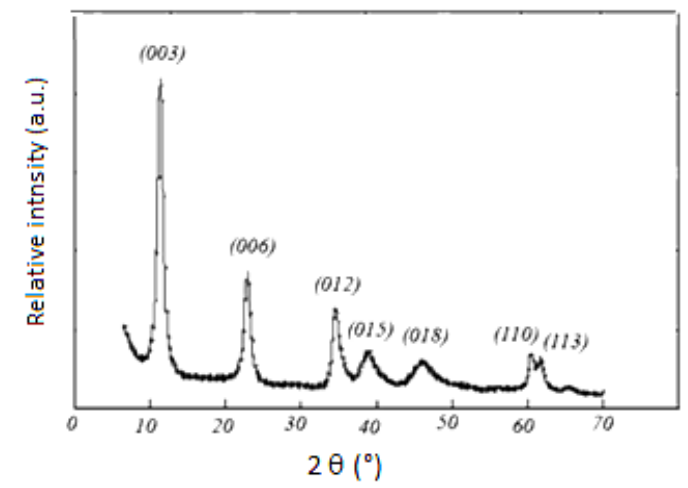

Figure.2. X-ray diffraction patterns of HT

\subsubsection{Infrared Spectroscopy}

The IR spectra of synthesized anion clays (Fig 2 ) resemble those of other hydrotalcite -like phases [19]:

The band at $3463 \mathrm{~cm}^{-1}$ which could be attributed to the stretching vibration of hydroxyl group. The low intensity band at $1637 \mathrm{~cm}^{-1}$ is assigned to bending vibration of strongly adsorbed water (solvation water for compensating anion vibration).

The band at $1381 \mathrm{~cm}^{-1}$ is assigned to carbonate vibration $\left(\mathrm{CO}_{3}{ }^{2-}\right)$, the bands at 672 and $436 \mathrm{~cm}^{-1}$ are respectively due to $\mathrm{M}-\mathrm{O}$ and $\mathrm{O}-\mathrm{M}-\mathrm{O}$ related to $\mathrm{LDH}$ layer ( $\mathrm{M}$ is a divalent or trivalent metal).

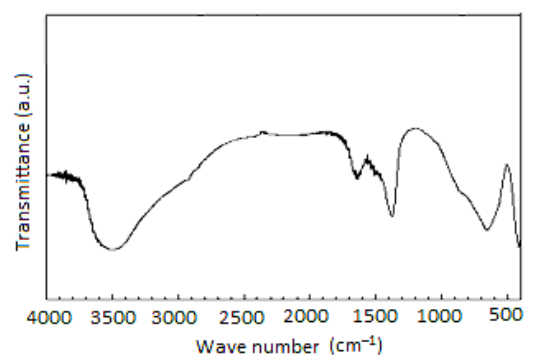

Figure.3. FTIR spectra for HT

\subsection{Batch Adsorption Studies}

\subsubsection{Effect of contact time}

The contact time between the pollutant and the adsorbent is an important parameter in treatment by adsorption. Fig. 4 shows the effect of contact time between the HT500 and AO7 dye solutions (40 and 80 $\mathrm{mg} / \mathrm{L}$ ). Thus, Rapid adsorption and equilibrium in a short period of time is related to the efficacy of the adsorbent, especially for wastewater treatment $[10,11]$.

Rapidabsorptioncan be associated withtheexistenceof a large numberof vacantsites at the surfaceofHT500andavailablefor adsorption. Equilibrium is reachedaftersaturationofthe entire surface. Furthermore, most of the adsorbate species are physically adsorbed within a short time frame. However, strong chemical bonds between the adsorbate and the adsorbent require a longer contact time to achieve equilibrium[11]

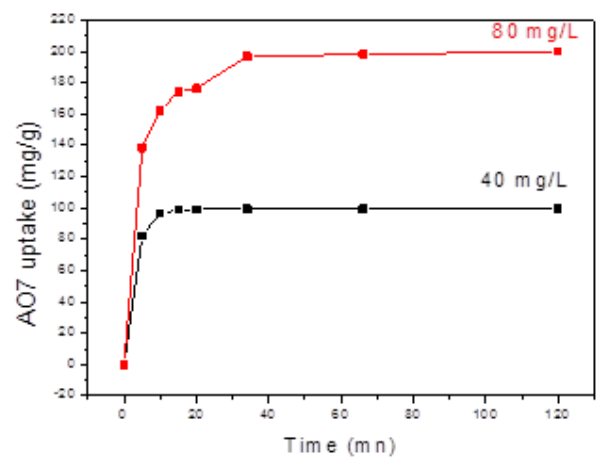

Figure.4.Effet of contact time on the uptake of AO7 by HT500, $\mathrm{m}_{\text {adsorbent }}=20 \mathrm{mg}, \mathrm{V}=50 \mathrm{ml}, \mathrm{T}=25^{\circ} \mathrm{C}, \mathrm{pH}=6$ 
Removal of textile dye by mixed oxide-LDH: kinetics, isotherms of the adsorption and ....

Theadsorption kinetic was analyzed by the pseudo first-order equation [21], i.e., (3) or pseudo-second order [2223], i.e.,(4).

$$
\begin{gathered}
\ln \left(\mathrm{q}_{\mathrm{e}}-\mathrm{q}_{\mathrm{t}}\right)=\ln \left(\mathrm{q}_{\mathrm{e}}\right)-\mathrm{t} \cdot \mathrm{K}_{1, \text { ads }} \text { i.e., }(3) \\
t / \mathrm{q}_{\mathrm{t}}=\mathrm{t} / \mathrm{q}_{\mathrm{e}}+1 /\left(\mathrm{q}_{\mathrm{e}}^{2} \cdot \mathrm{K}_{2, \text { ads }}\right) \quad \text { i.e., (4) }
\end{gathered}
$$

$\mathrm{q}_{\mathrm{e}}$ and $\mathrm{q}_{\mathrm{t}}$ are the amounts of AO7 adsorbed by HT500 respectively at equilibrium and $\mathrm{t}, \mathrm{K}_{1, \text { ads }}$ and $\mathrm{K}_{2, \text { ads }}$, the adsorption constants. The experimental equilibrium data can be fitted by i.e..(3) and (4), the value of $\mathrm{R}^{2}$ indicates that AO7adsorption is successfully fitted by pseudo-second-order model.

Table 1.Fitting parameters for the AO7 adsorption kinetic models

\begin{tabular}{|c|c|c|c|c|c|}
\hline \multicolumn{3}{|c|}{ Pseudo first-ordermodel } & \multicolumn{3}{c|}{ Pseudo-second order model } \\
\hline $\mathrm{K}_{1, \text { ads }}\left(\mathrm{min}^{-1}\right)$ & $\mathrm{q}_{\mathrm{e}}(\mathrm{mg} / \mathrm{g})$ & $\mathrm{R}^{2}$ & $\mathrm{~K}_{2, \text { ads }}(\mathrm{g} / \mathrm{mg} / \mathrm{min})$ & $\mathrm{q}_{\mathrm{e}}(\mathrm{mg} / \mathrm{g})$ & $\mathrm{R}^{2}$ \\
\hline 0,047 & 131,82 & 0,94 & 0,002 & 204,49 & 0,99 \\
\hline
\end{tabular}

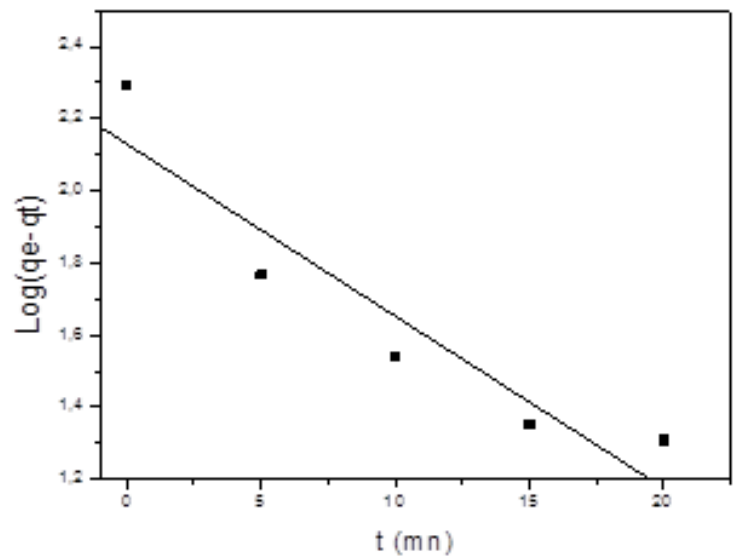

Figure.5. Pseudo-first-order kinetic plots of sorption of AO7 on HT500

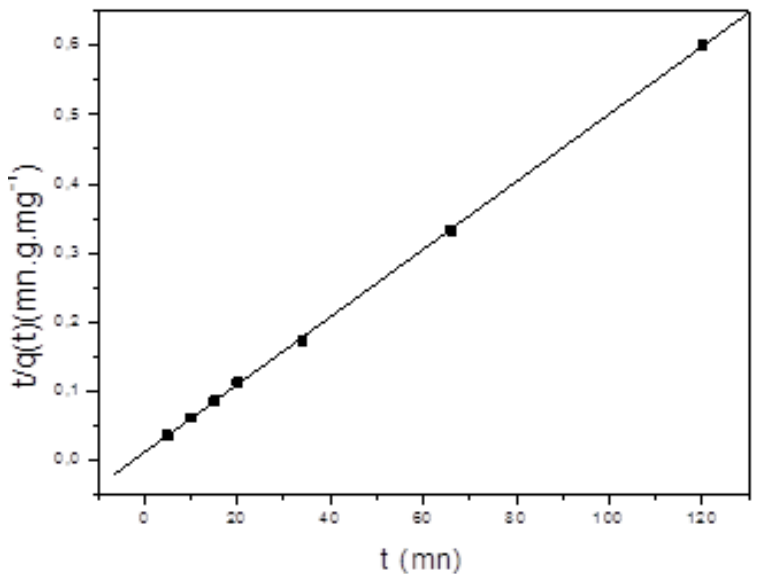

Figure.6. Pseudo-second-order kinetic plots of sorption of AO7 on HT500

By comparing the two models, we can say that the adsorption kinetics of AO7 by HT500 obeys a law of pseudosecond order.

\subsubsection{Intradiffusion}

The intra-particle diffusion approach [24] can be used to predict if intra-particle diffusion is the ratelimiting step. The experiment data exhibit multi-linear plots, revealing that the process is governed by two steps (Fig. 6). The first linear portion (phase I) at both concentrations can be attributed to the immediate utilization of the available sites on the sorbent surface. In contrast the phase II may be attributed to very slow diffusion of the sorbate from the surface site into the inner pores. Thus the initial portion of AO7 dye sorption by HT500 may be governed by the initial intra-particle transport of AO7 dye controlled by surface diffusion process and the later 
part controlled by pore diffusion. The values of $\mathrm{k}_{\mathrm{ip} 1}$ and $\mathrm{k}_{\mathrm{ip} 2}$ (diffusion rate constants for phases I and II, respectively) obtained from the slope of linear plots are listed in Table 2 (Weber and Morrismodel).

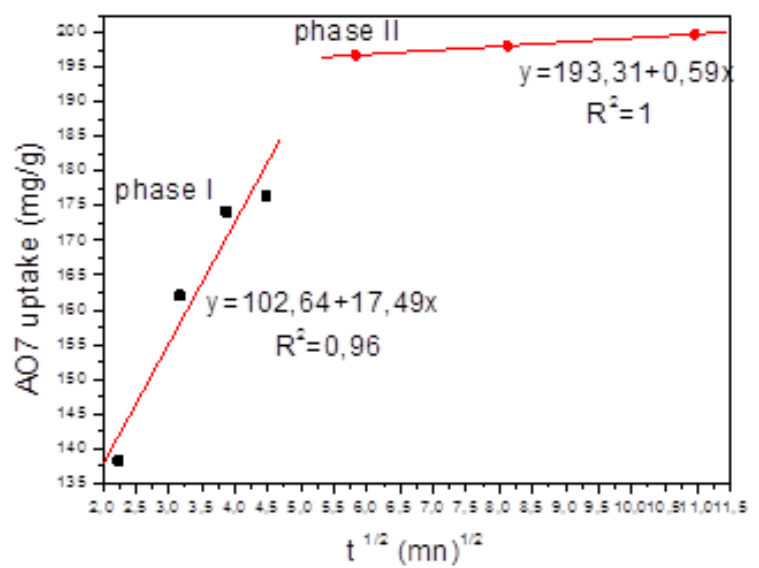

Figure.7.Intra-particle diffusion plots of sorption of AO7 on HT500.

Table2.Parameters of Weber and Morrismodel

\begin{tabular}{|c|c|c|c|c|}
\hline \multirow{2}{*}{$\mathrm{q}_{\mathrm{t}}=\mathrm{k}_{\mathrm{ip}} \mathrm{t}^{1 / 2}+\mathrm{C}$} & $\mathrm{K}_{1 \mathrm{p}}$ & $\mathrm{R}^{2}$ & $\mathrm{~K}_{2 \mathrm{p}}$ & $\mathrm{R}^{2}$ \\
\cline { 2 - 5 } & 17,496 & 0,96 & 0,59 & 1 \\
\hline
\end{tabular}

\subsubsection{Effect of adsorbent mass}

The influence ofadsorbent mass was studied in the range 5 to $100 \mathrm{mg}$. Fig 8 shows that, for a concentration of AO7 $40 \mathrm{mg} / \mathrm{l}$, for a time equilibrium $\left(\mathrm{t}_{\mathrm{e}}=34 \mathrm{mn}\right)$, an increase of adsorbent mass from $5 \mathrm{mg}$ to $100 \mathrm{mg}$ causes a decrease of the residual concentration (Ce) from $16 \mathrm{mg}$ to $0,46 \mathrm{mg} /$.Thus, optimal adsorbent mass of HT500 is $20 \mathrm{mg}$ to remove $97 \%$.of AO7.

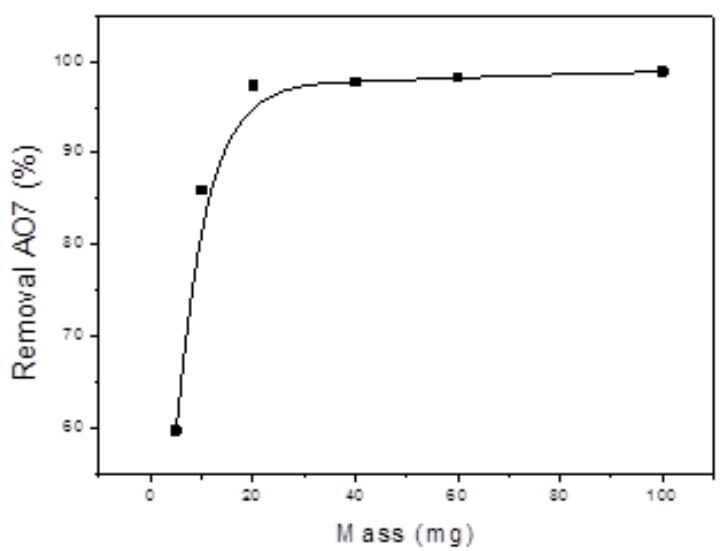

Figure.8. Effect of dose adsorbent on the adsorption of AO7 by HT500, te $=34 \mathrm{mn}[\mathrm{AO} 7]=40 \mathrm{mg} / \mathrm{L} \mathrm{pH=6}$ $\mathrm{T}: 25^{\circ} \mathrm{C}$

\subsubsection{Effect of $\mathbf{p H}$}

Several parameters such as adsorption capacity of adsorbent, surface charges and active sites may be attributed to the adsorption behavior of the adsorbent at various $\mathrm{pH}$.

The surface of HT500 contains a large number of active sites. The dye uptake can be related to the active sites and also to the chemistry of the dye in the solution. Theoretically, at $\mathrm{pH}<$ point of zero charge (PZC), the surface gets positively charged, which enhances the adsorption of the negatively charged dye anions through electrostatic forces of attraction. At $\mathrm{pH}>(\mathrm{PZC})$, the surface of HT500 particles gets negatively charged, which favors the adsorption of cationic dye [25].

These results are similar to the adsorption of Congo Red onto $\mathrm{Mg}-\mathrm{Fe}-\mathrm{CO}_{3}-\mathrm{LDH}$.[26]. 


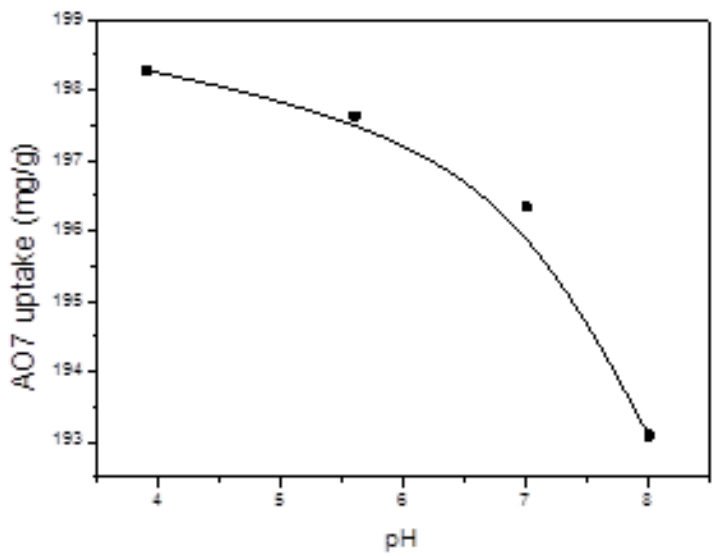

Figure.9.Effectof initial $\mathrm{pH}$ on the adsorption of $\mathrm{AO} 7$ by HT500, te $=34 \mathrm{mn}[\mathrm{AO} 7]=80 \mathrm{mg} / \mathrm{L}$ $\mathrm{m}_{\mathrm{HT}}=20 \mathrm{mg}, \mathrm{T}=25^{\circ} \mathrm{C}$

\subsubsection{Adsorption isotherm}

Fig. 10 shows the behavior of the adsorption isotherm of AO7 dye in HT500. We observe that the adsorbed amount of AO7 increased rapidly from 74,58 to $148,37 \mathrm{mg} / \mathrm{g}$ at a relatively low AO7 initial concentration (from 30 to $60 \mathrm{mg} / \mathrm{L}$ ). The initial sharp rise in the isotherm indicates the availability of readily accessible sites for adsorption. However, site saturation occurs as the AO7 concentration increases (from 80 to $120 \mathrm{mg} / \mathrm{l}$ ) and a plateau is reached indicating that no more sites remain available for adsorption following the saturation of the adsorbent sites taken at a fixed dose, and this happens when the adsorption equilibrium is reached [27].The model of the isotherm (isotherm type I) obtained is similar to the mathematical model of Langmuir.The sorption data was further analyzed using Langmuir model (Fig.11), which can be expressed as follows:

$$
\mathrm{C}_{\mathrm{e}} / \mathrm{Q}=\mathrm{C}_{\mathrm{e}} / \mathrm{Q}_{\mathrm{m}}+1 / \mathrm{K} \text { Q } \mathrm{m} \text { i.e..(5) }
$$

$\mathrm{Q}(\mathrm{mg} / \mathrm{g})$ : denotesthe adsorbed amount of AO7 per unit mass of adsorbent HT500.

$\mathrm{Q}_{\mathrm{m}}(\mathrm{mg} / \mathrm{g})$ : the Langmuir constant representing maximum monolayer sorption capacity ofl'HT500.

$\mathrm{Ce}(\mathrm{mg} / \mathrm{L})$ : the equilibrium adsorption concentration of $\mathrm{AO} 7$ in solution.

$\mathrm{K}(\mathrm{L} / \mathrm{mg})$ :Langmuir constant related to energy of sorption.

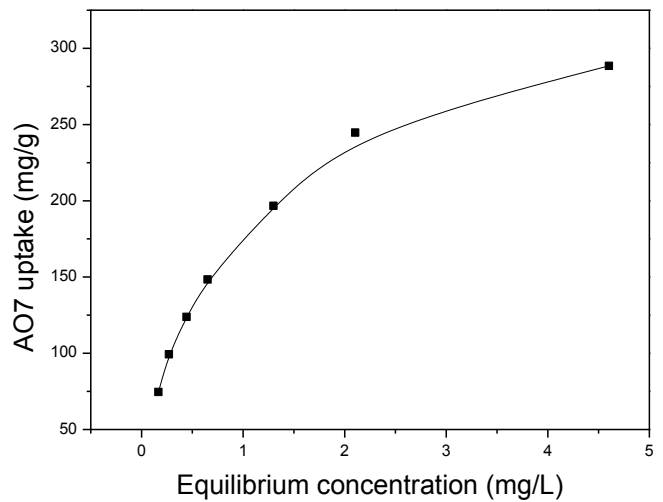

Figure.10. Isotherms of $\mathrm{AO} 7$ adsorption onto $\mathrm{HT} 500$ at $25^{\circ} \mathrm{C}$ and $\mathrm{pH} 6$ 


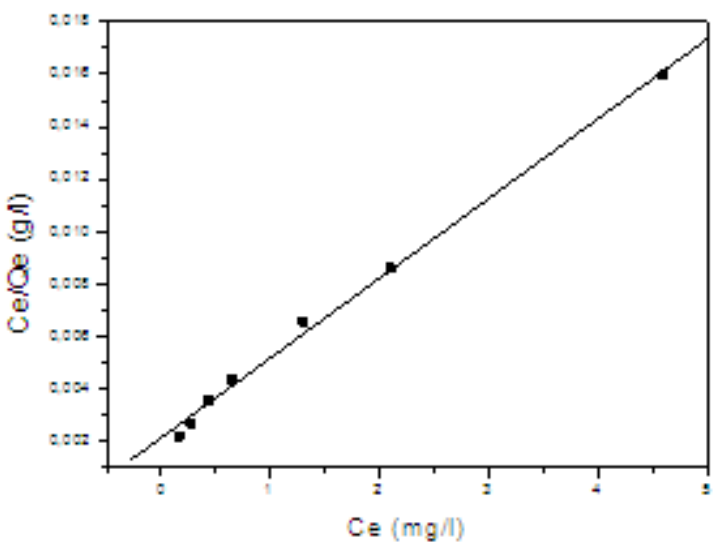

Figure 11.Fitting lines of the Langmuir adsorption isotherms of AO7 on HT500

Table 3 shows values constants of Langmuir.The maximumamount absorbedper unit mass of ouradsorbent whichisin the order of $328.94 \mathrm{mg} /$ gis large enoughcomparedto those foundin the literature (Table4).

Table 3.Parameters of Langmuir for the retention of AO7byHT500

\begin{tabular}{|c|c|c|}
\hline $\mathrm{Qm}(\mathrm{mg} / \mathrm{g})$ & $\mathrm{K}(\mathrm{L} / \mathrm{mg})$. & $\mathrm{R}^{2}$ \\
\hline 328,94 & 1,4 & 0,999 \\
\hline
\end{tabular}

The influence of adsorption isotherm shape has been discussed [28]to examine whetheradsorption is favorable in terms of ' $R_{\mathrm{L}}$ ', a dimensionless constant referred to as separation factor or equilibrium parameter. ' $\mathrm{R}_{\mathrm{L}}$ ' is calculated using the equation below:

$$
\mathrm{R}_{\mathrm{L}}=1 / 1+\mathrm{KC}_{0} \quad \text { i.e..(6) }
$$

Where $\mathrm{K}\left(\mathrm{L} \mathrm{mg}^{-1}\right)$ is the Langmuir constant and $\mathrm{C}_{0}\left(\mathrm{mg} \mathrm{L}^{-1}\right)$ is the initial concentration in the liquid phase. $R_{L}$ represents the dimensionless parameter of the equilibrium or adsorption intensity. The value of $R_{L}$ indicates the type of the isotherm to be either favorable $\left(0<\mathrm{R}_{\mathrm{L}}<1\right)$, unfavorable $\left(\mathrm{R}_{\mathrm{L}}>1\right)$, linear $\left(\mathrm{R}_{\mathrm{L}}=1\right)$ or irreversible $\left(\mathrm{R}_{\mathrm{L}}=0\right)$. The $\mathrm{R}_{\mathrm{L}}$ value obtained $\left(8,8410^{-3}\right)$ shows a type of favorable equilibrium. This value which is close to the irreversible type is consistent with the type of interaction between adsorbate-adsorbent that is usually done in the case of HDL by hydrogen bonds which lies at the border of the physical link and the chemical.

Table 4.Adsorption capacityobtainedwith otheradsorbenton eliminatingFCF $\left(\mathrm{C}_{16} \mathrm{H}_{10} \mathrm{~N}_{2} \mathrm{Na}_{2} \mathrm{O}_{7} \mathrm{~S}_{2}\right)$ dye whichis similar toAO7

\begin{tabular}{|l|c|c|c|c|}
\hline Adsorbents & Adsorption capacity $(\mathrm{mg} / \mathrm{g})$ & $\mathrm{pH}$ & Concentration range $(\mathrm{mg} / \mathrm{L})$ & References \\
\hline Amberlite FPA51 & 130,6 & $\sim 4.87$ & $100-1500$ & {$[30]$} \\
\hline Maggrovebark & 12.72 & 2 & - & {$[31]$} \\
\hline Cd(OH)2-NW-AC & 76.92 & 1 & $50-200$ & {$[32]$} \\
\hline Ag-NP-AC & 37.04 & 1 & $50-200$ & {$[32]$} \\
\hline CdTN-AC & 181.81 & 1 & $25-150$ & {$[33]$} \\
\hline CaAl-LDH-NO3 & 398.41 & 4 & $10-1000$ & {$[29]$} \\
\hline HT500 & 328,94 & 4 & - & This work \\
\hline
\end{tabular}

AC: activatedcarbon; CdTN: cadmium telluridenanoparticles; NW: nanowires; NP: nanoparticles

\subsubsection{Retention mechanism}

The intraparticle diffusion, the maximum absorbed and obtained amount and the calculated value of $R_{L}$ (Type equilibrium) assume that the retention of AO7 by HT500 is a reconstruction reaction, usually encountered when contacting a HDL mixed oxide based on magnesium and aluminum with an anion [34]. In this case the retention mechanism makes a dye adsorption at the surface and by intercalation within the regenerated HDL.

This result is confirmed by the characterization of the product recuperated after adsorption by SEM and XRD. In effect, the X diffractogram obtained (Fig 12) shows the shape type of a HDL. Thus, the interlamellar distance of the order of $7.9406 \AA$ is raised in accordance with a parallel arrangement by the interposed HDL and AO7.

Regeneration HT-AO7 was also confirmed by SEM. Indeed, SEM photographs taken at the same scale, obtained before and after adsorption, are reported respectively (Fig 13 and 14).The SEM micrograph of the HT500 revealed the collapsed layer structure, which further indicated that the HT transforms to mixed magnesium and aluminum oxides. While the plate of Fig 14 corresponding to the after adsorption of AO7 shows the presence of interlamellar sheet confirming the formation of HT after reaction of reconstruction. 


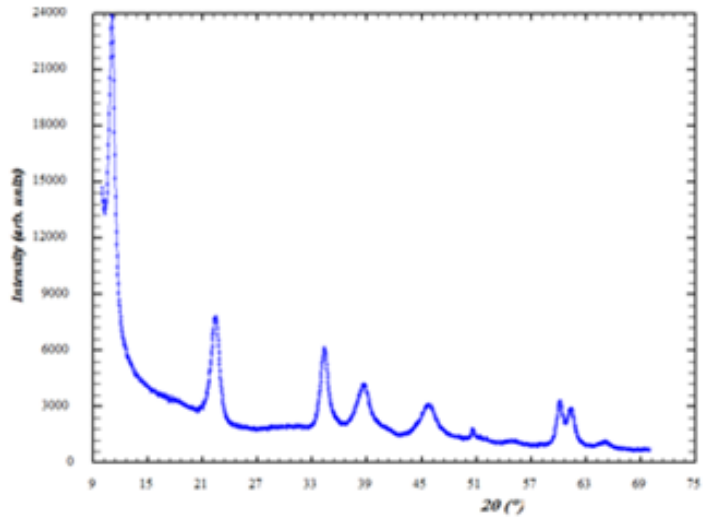

Figure.12. XRD pattern of HT500 after adsorption
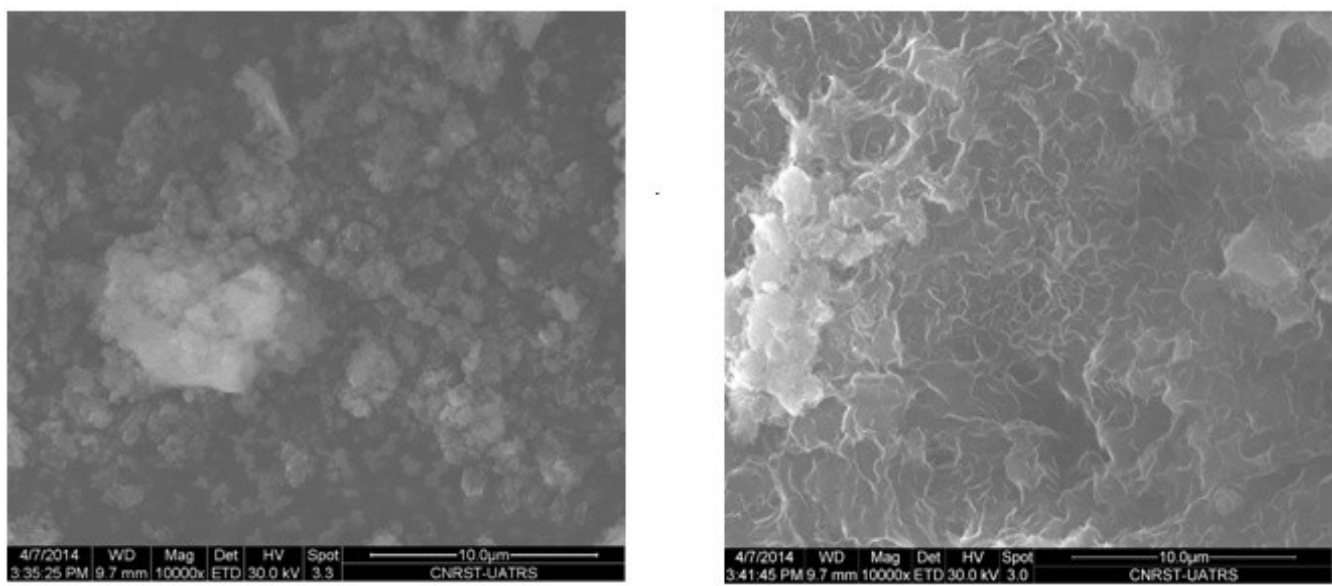

Figure.13. SEM images of HT500Figure.14.SEM images of HT500 after adsorption

\section{Conclusion}

The results of the tests conducted during this study allowed us to optimize the parameters of adsorption of the dye AO7 by HT500 prepared, namely the equilibrium time, $\mathrm{pH}$, dose of the adsorbate and the mass of the adsorbent.

he results related to the kinetics and adsorption isotherms have been exploited to clarify the method of fixing the dye on the adsorbent. Adsorption of AO7 on HT500 follows the pseudo second-order model. The intra-particle diffusion approach can be used to predict if intra-particle diffusion is the rate-limiting step. The adsorption isotherm results could be fitted by the Langmuir isotherm model, which is a better model. The equilibrium parameter $0<\mathrm{R}_{\mathrm{L}}<1$ represents a favorable adsorption. The dye molecules are then adsorbed monolayers, without dye-dye interactions, thereby increasing the order of their distribution on the surface. The maximum amount of dye retained $\mathrm{mg} / \mathrm{g}$ of adsorbent which is in the order of $328 \mathrm{mg} / \mathrm{g}$ shows a high efficiency of our adsorbent. The results of XRD, and SEM, demonstrate that the main adsorption mechanism involves the rehydration of mixed metal oxides and concomitant intercalation of $\mathrm{AO} 7$ dye into the interlayer to reconstruct the initial HT structure.

\section{References}

[1]. V.K. Gupta, Suhas, Application of low-cost adsorbents for dye removal - a review, J. Environ. Manage. 90 (2009) $2313-2342$.

[2]. D. Shen, J. Fan, W. Zhou, B. Gao, Q. Yue, Q. Kang, Adsorption kinetics and isotherm of anionic dyes onto organo-bentonite from single and multisolutesystems, J. Hazard. Mater. 172 (2009) 99-107.

[3]. M. Rafatullaha, O. Sulaimana, R. Hashima, A. Ahmad, Adsorption of methylene blue on low-cost adsorbents: a review, J. Hazard. Mater. 177 (2010) 70-80.

[4]. A. Zahrim, C. Tizaoui, N. Hilal, Evaluation of several commercial synthetic polymers as flocculant aids for removal of highly concentrated C.I. Acid Black210 dye, J. Hazard. Mater. 182 (2010) 624-630.

[5]. E. Haque, J.W. Jun, S.H. Jhung, Adsorptive removal of methyl orange and methylene blue from aqueous solution with a metalorganic frameworkmaterial, iron terephthalate (MOF-235), J. Hazard. Mater. 185 (2011) 507-511.

[6]. P. Zhang, G. Qian, H. Shi, X. Ruan, J. Yang, R.L. Frost, Mechanism of interaction of hydrocalumites (Ca/Al-LDH) with methyl orange and acidic scarlet GR, J.Colloid Interface Sci. 365 (2012) 110-116.

[7]. U. V. Ladhe, P. R. Patil, Removal of Yellow $2 \mathrm{G}$ dye from aqueous solutions using activated carbon prepared from mosambi and cotton an agricultural waste, IOSR-JESTFT 8(1) (2014), 49-54 
[8]. JannatulFerdousRumky, ZainalAbedin, HafizurRahman, Ali Hossain, Environmental Treatment of Dyes: Methyl Orange Decolorization Using Hog Plum Peel and Mix-Bacterial Strains, IOSR-JESTFT, 5(3) (2013), 19-22

[9]. M.-X. Zhu, L. Lee, H.-H. Wang, Z. Wang, Removal of an anionic dye by adsorption/precipitation processes using alkaline white mud, J. Hazard. Mater.149 (2007) 735-741.

[10]. G.L. Dotto, L.A.A. Pinto, Adsorption of food dyes acid blue 9 and food yellow 3 onto chitosan: stirring rate effect in kinetics and mechanism, J. Hazard. Mater.187 (2011) 164-170.

[11]. I.D. Mall, V.C. Srivastava, N.K. Agarwal, Removal of Orange-G and Methyl Violet dyes by adsorption onto bagasse fly ash-kinetic study and equilibrium isotherm analyses, Dyes Pigments 69 (2006) 210-223.

[12]. D.A. Fungaro, M. Bruno, Removal of methylene blue from aqueous solution using zeolite synthesized from different coal fly ashes samples, Quím. Nova 32 (2009) 955-959.

[13]. H.-Y. Zhu, Y.-Q.Fu, R. Jiang, J.-H.Jiang, L. Xiao, G.-M.Zeng, S.-L.Zha, Y. Wang, Adsorption removal of congo red onto magneticcellulose/Fe3O4/activated carbon composite: equilibrium, kinetic and thermodynamic studies, Chem.Eng. J. 173 (2011) 494-502.

[14]. S. Dawood, T.K. Sen, Removal of anionic dye congo red from aqueous solution by raw pine and acid-treated pine cone powder as adsorbent: Equilibrium,thermodynamic, kinetics, mechanism and process design, Water Res. 46 (2012) $1933-1946$.

[15]. El MouloudiSabbar, Marie Elisabeth de Roy, Fabrice Leroux. New Cu and/or Pt complexes intercalated MgAl- hydrotalcite-type anionic clays: synthesis, characterization, thermal behavior and textural properties.Microporous and mesoporeuxMatereil, 103, 2007, 134-141

[16]. El MouloudiSabbar, Marie Elisabeth de Roy, Fabrice Leroux. Probing the interaction between di- and tri-functionalized carboxyphosphonique acid and LDH layer structure.Journal of Physics and Chemistry of Solids 67, 2006, 2419-2429

[17]. N. Sadik, E. Sabbar, M. Mountadar. Elimination of the pesticides by synthesized anion clays starting from marine water. J. Mater. Environ. Sci. 3 (2), 2012, 379-390

[18]. WT. Reichle. Solid State Ionics, 22 (1986) 135-141.

[19]. L. Lv, J. He, M. Wei, DG.Evans, X. Duan. Water Research, 40(4) (2006) $735-743$.

[20]. Y. Li, B. Gao, T. Wu, B. Wang, X. Li. Journal of Hazardous Materials, 164 (2009) 1098-1104

[21]. S. Lagergren, ZurTheorie der sogenannten Adsorption gelostn. Stoffe.Stcok.Ak. Handl.Bihay. 24 (Afd. 1), 39 (1898).

[22]. Y.S. Ho, Adsorption of heavy metals from waste streams by peat. PhD Thesis.Birmingham,UK, University of Birmingham.(1995).

[23]. Y.S. Ho, G. Mckay, The kinetic of sorption of divalent metal ions onto sphagnum moss peat. Water Res., 34, 735-742(2000).

[24]. W. J. Weber, J.C. Morris,.Kinetics of adsorption on carbon from solution.J. Sanit. Eng. Div. ASCE., 89: 31-60 (1963)

[25]. R. Liikanen, J. Yli-Kuivila, J. Tenhunen, R. Laukkanen, Desalination 201 (1-3) (2006) 58

[26]. I.M. Ahmed, M.S. GasserAdsorption study of anionic reactive dye from aqueous solution to $\mathrm{Mg}-\mathrm{Fe}-\mathrm{CO} 3$ layered double hydroxide (LDH)Applied Surface Science 259 (2012) 650-656

[27]. Fernando Pereira de Sà, Beatriz Nogueira Cunha, LilianeMagalhaesNunes,Effect of pH on the adsorption of Sunset Yellow FCF food dye into a layered double hydroxide (CaAl-LDH-NO3) Chemical Engineering Journal 215-216 (2013) 122-127

[28]. R. Hall, L.C. Eagleaton, A. Acrivos, T. Vermeulen, Pore- and Solid-Diffusion Kinetics in Fixed-Bed Adsorption under ConstantPattern Conditions, Ind. Eng. Chem. Fundam. 5 (1966) 212-223.

[29]. Fernando Pereira de Sà, Beatriz Nogueira Cunha, LilianeMagalhaesNunes,Effect of pH on the adsorption of Sunset Yellow FCF food dye into a layered double hydroxide (CaAl-LDH-NO3) Chemical Engineering Journal 215-216 (2013) 122-127

[30]. M. Wawrzkiewicz, Sorption of Sunset Yellow dye by weak base anion exchanger - kinetic and equilibrium studie, Environ. Technol. 32 (2011) 455-465.

[31]. T.L. Seey, M.J.N.M. Kassim, Acidic and basic dyes removal by adsorption on chemically treated mangrove barks, Int. J. Appl. Sci. Technol. 2 (2012) 270-276.

[32]. M. Ghaedi, Comparison of cadmium hydroxide nanowires and silver nanoparticles loaded on activated carbon as new adsorbents for efficientremoval of Sunset Yellow: kinetics and equilibrium study, Spectrochim. Acta Part A 94 (2012) 346-351.

[33]. M. Ghaedi, A.H. Jah, S. Khodadoust, R. Sahraei, A. Daneshfar, A. Mihandoost, M.K. Purkait, Cadmium telluride nanoparticles loaded on activated carbon as adsorbent for removal of sunset yellow, Spectrochim. Acta Part A 90 (2012) 22-27.

[34]. Miyata, S, Physico-chemical properties of synthetic hydrotalcites in relation to com-position.Clays and Clay Minerals 28, (1980)5056. 